UDC 629.735.018.006.26:629.7.05/.06 (045),

DOI: $10.18372 / 1990-5548.52 .11871$

${ }^{1}$ V. M. Sineglazov,

${ }^{2}$ S. O. Dolgorukov

\title{
ENVIRONMENTAL CHAMBER FOR NAVIGATION EQUIPMENT TEST TABLE
}

\author{
${ }^{1,2}$ Educational \& Research Institute of Information and Diagnostic Systems, National Aviation University, \\ Kyiv, Ukraine \\ E-mails: ${ }^{1}$ svm@nau.edu.ua, ${ }^{2}$ sdolgorukov@nau.edu.ua
}

\begin{abstract}
Environmental thermal chambers are essential tool for testing navigation equipment in conditions close to real. This article describes the design and operating characteristics of thermal chambers with respect to application in various technology microelectromechanical systems testing. The design choices and optimization are taking into account that thermal camera must operate inside the inner frame of three axes test table. Thermal chamber optimal choice for testing microelectromechanical systems based inertial measurement units are driven by four main areas with respect to navigation equipment test laboratory. Discussed is the chamber design and characteristics that minimizes constaruction and operating cost of the system.
\end{abstract}

Index Terms-Environmental testing; microelectromechanical systems; simulation table; measurement error.

\section{INTRODUCTION}

Ensuring measurement quality of Microelectromechanical systems (MEMS) devices over their specified operating range, especially industrial sensors, they typically need thermal testing at different stages of the production cycle. Combined with 3 -axis simulation table complex tests can be performed with extended results. It requires that engineering look not only at device size and test specifications, but also consider operations need to conserve floor space and maximize flexibility. Achieving quality goals involves many points of thermal stress including conditioning, verification, calibration, life testing, design qualification, failure analysis, quality checks, and regulatory audits.

Optimizing controlled thermal environments for testing MEMS industrial measurement devices depends on four areas:

1. Test being performed. Thermal and dynamic profile.

2. Device under test (DUT).

3. Throughput goals and test requirements.

4. Facility infrastructure. Power, Ventilation, Laboratory footprint.

The test environment is subject to many interrelated variables and we will discuss the above points taking into account existing Navigation Eqipment Test Laboratory (NETL) in National Aviation University.

\section{INERTIAL NAVIGATION SYSTEMS TEST PROBLEM STATEMENT}

An Inertial Navigation System (INS) uses the output from an Inertial Measurement Unit (IMU), then it combines the information on acceleration and rotation with initial information about position, velocity and attitude. Microelectromechanical systems accelerometers and gyros used in IMUs have three common error sources: bias $(b)$, scale factor $(S)$ and random sensor noise error (e) [1], [3]. Moreover, $b$ and $S$ are subject to variations due to environmental changes such as temperature (Fig. 1). The following single axis equation represent MEMS sensor error components:

$$
x=S f(x)+b+e,
$$

where $x$ is the measured value and $f(x)$ is the true value about the sensitive axis.

Technology MEMS device is produced impact environmental stability and amount of measurement error - for capacitive being the most temperature stable and piezoresistive is the most non-temperature proof [2], Fig. 2.

\section{TEST CHAMBER OPTIMAL DESIGN PROCEDURE}

Microelectromechanical systems device (circuit, sensor, assembled housing) size, mass, and number of DUTs will be a factor in determining enclosure size. Usually it is several square millimeters for sensor and several square centimeters for MEMS PCB assembly.

Cooling test subjects effectively depends on test requirements, facility resources, and cost considerations. Usually matching the test subject's geometry to an appropriately sized chamber, platform, or test enclosure is an important first step when selecting a temperature system.

Chamber must be configured for device size, temperature range, transition speed and device access. 


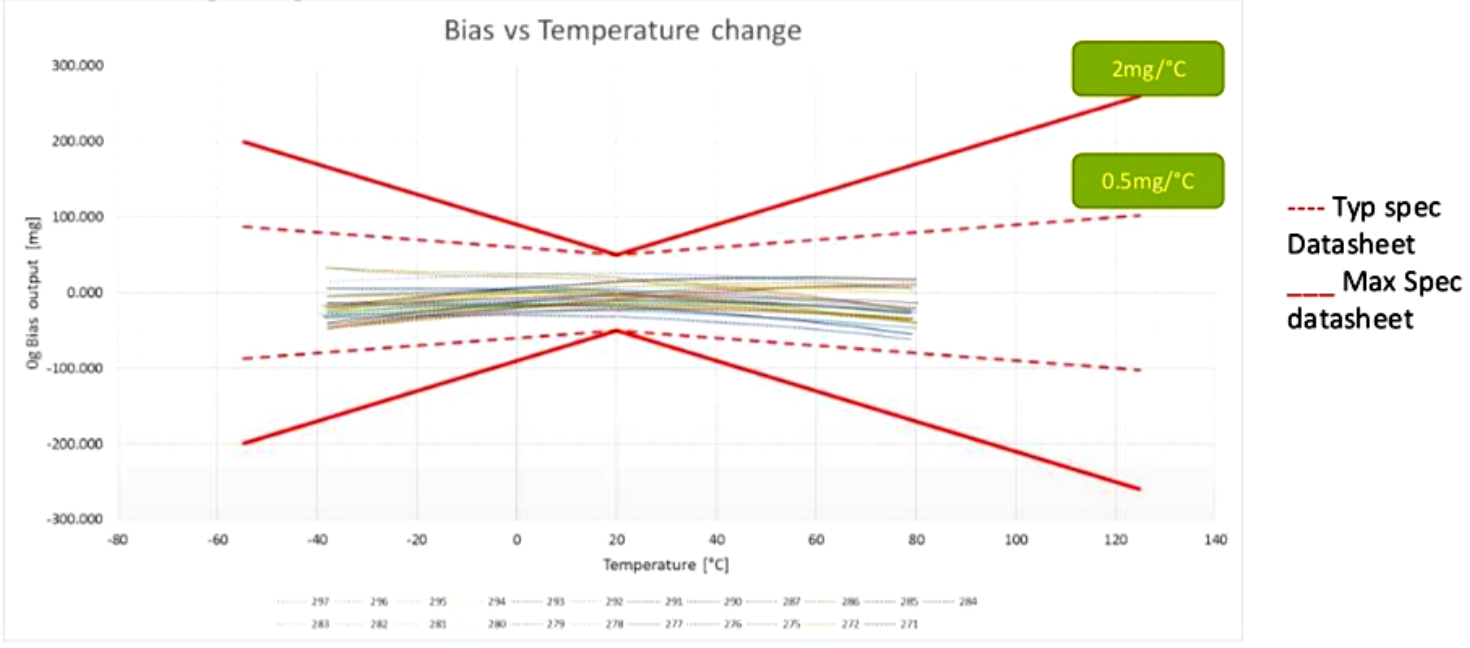

Fig. 1. Bias vs temperature of Colibrys MS9010.D accelerometer. $10 \mathrm{~g}$ range, measured -40 to $80{ }^{\circ} \mathrm{C}$

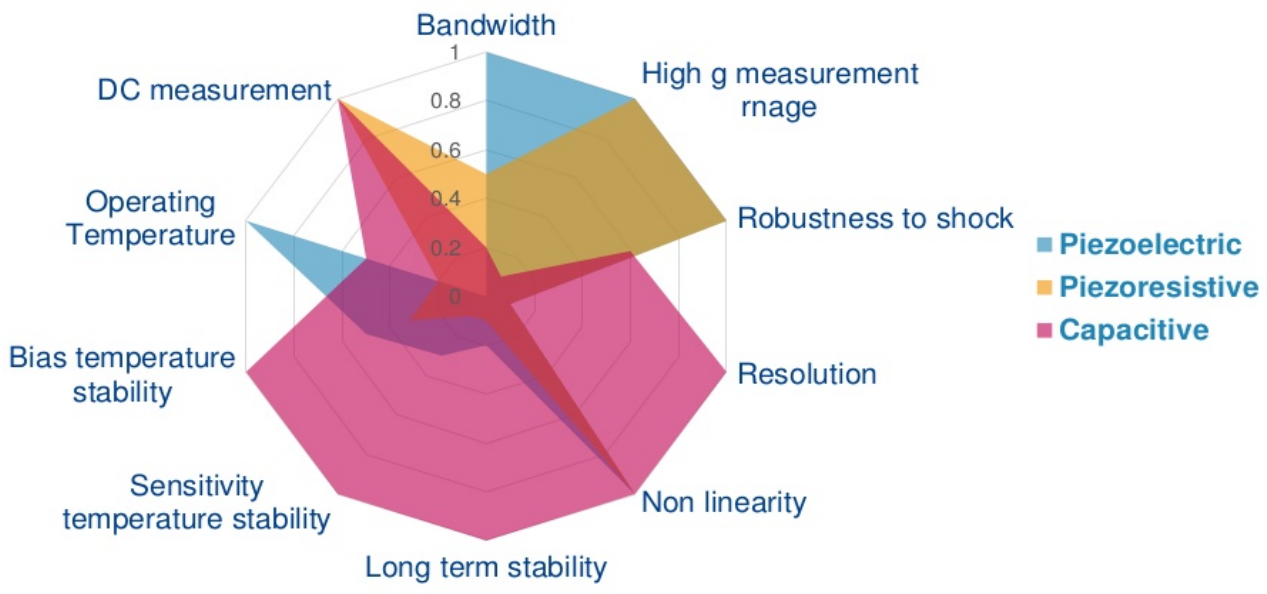

Fig. 2. Microelectromechanical systems accelerometers technologies comparison

Temperature platforms that provide an open work surface also known as "hot/cold plates". They are ideal for testing or conditioning low profile items with a flat surface such as RF devices and high density power device testing (IGBTs and MOSFETs).

Enclosure type that matches device will provide the best performance, reduce heat loss while allowing convenient access to devices. Enclosures attach directly to a nozzle or remotely via a hose.

The electronics for MEMS sensors tend to be small and low mass items. Often, these circuits can be conditioned in a small enclosure driven by a thermal cycler. The enclosure can also accommodate multiple circuit boards. For devices sensitive to thermal shock, enclosure designs can disperse air around the circuits to prevent direct exposure to the temperature source, as shown in Fig. 3 right.

The key considerations for each cooling method for the system must take into account the following.

Temperature range of industrial and consumer MEMS-based devices are in range minus 40 to $+125^{\circ} \mathrm{C}$. Military and aerospace capacitive sensors may reach minus 55 to $+150^{\circ} \mathrm{C}$, piezo sensors minus 55 to $+350^{\circ} \mathrm{C}[4]$.
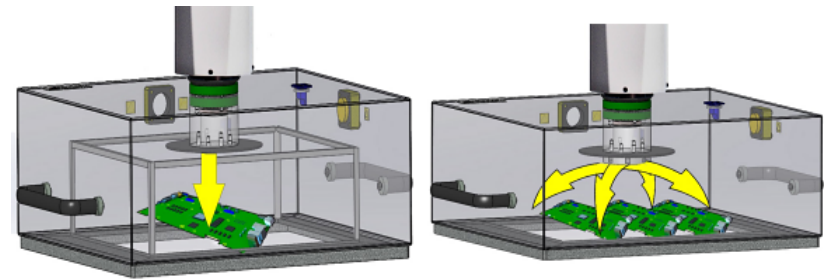

Fig. 3. Air source directly on DUT (left) and directed at sides of enclosure (right)

Compressor-based cooling uses compressors and conventional refrigerants in a single stage or cascade closed-loop system. Cryogenic cooling uses expendable Liquid Nitrogen $\left(\mathrm{LN}_{2}\right)$ or Liquid Carbon Dioxide $\left(\mathrm{LCO}_{2}\right)$ in an open loop system.

1) Temperature Test Requirements - Temperature Ranges, Transition Rates, and Dwell Times.

Cryogenic cooling offers the widest temperature ranges (minus 185 to $+500^{\circ} \mathrm{C}$, Fig. 4) with the fastest temperature transition rates (up to $100^{\circ} \mathrm{C} / \mathrm{min}$, Fig. 5) [5]. 


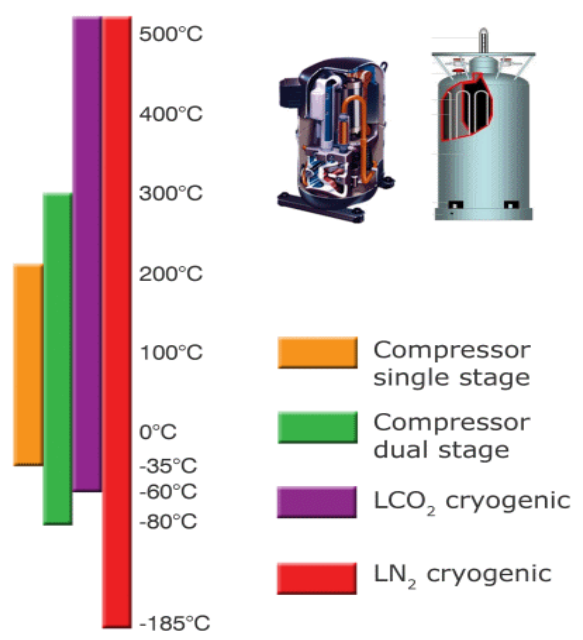

Fig. 4. Cooling system temperature range

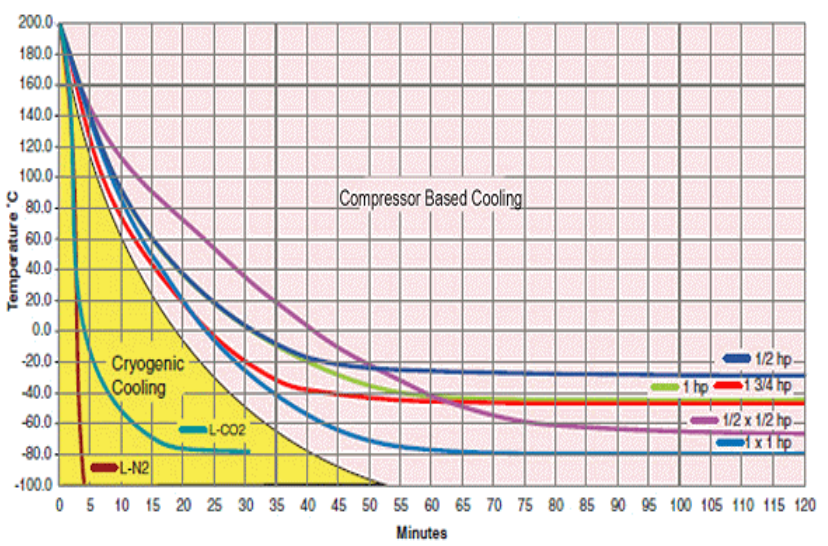

Fig. 5. Cooling system transition rates

Compressor-based systems (minus 100 to $+300^{\circ} \mathrm{C}, 10^{\circ} \mathrm{C} / \mathrm{min}$ ) are better suited for long dwell times because a closed-loop system does not require expendable coolants. It is also worth considering that compressor-based systems have high temperature limitations because conventional refrigerants break down in ultra-high temperature applications.

If both cryogenic and compressor-based systems can meet test specifications, facility requirements and system cost are the next considerations.

I our case for consumer grade MEMS DUTs the single stage compressor-based system may be suitable.

2) Facility Resources - Coolant Supply, Coolant Exhaust, Facility Power, and System Footprint.

If the facility is equipped with an LN2 or LCO2 bulk-delivery system, cryogenic cooling will be the easiest to integrate. Without bulk-delivery, cryogenic systems rely on dewars (portable tanks) to deliver coolant. Dewars can be cumbersome and may deplete before testing is finished.

Regardless of the coolant delivery method, all cryogenic systems expel exhaust that must be managed. Cryogenic exhaust is a result of the liquid coolant becoming gaseous and expanding at a ratio of up to 1:700. These large volumes of gas can force breathable oxygen out of rooms that are not properly vented. Managing cryogenic exhaust requires either venting the exhaust to the outside atmosphere or installing the system in a well vented area with an oxygen monitor nearby.

Compressor-based systems are closed loop systems that do not produce gaseous exhaust, but they do generate mechanical noise and heat. In some cases, steps must be taken to manage the heat especially if multiple compressor-based systems will be employed within a small area. Options for managing the heat include fans and ventilation or water-cooled condenser units.

Facility's power limitations must also be considered. Compressors and heaters require energy and as temperature ranges and transition rates increase, so too do the system's heating and cooling power requirements. Compressor-based systems typically require a minimum of $220 \mathrm{~V}, 30 \mathrm{~A}$ whereas cryogenic systems can operate on as little as $220 \mathrm{~V}, 5 \mathrm{~A}$. And while both cooling systems can require high power, cryogenic systems typically stay within 30 A because they do not rely on compressors for cooling.

The cooling system's size also play a role if floor space is at a premium. Cryogenic systems can be stacked, allowing multiple chambers to operate in the same footprint.

For the NETL facility the most cost effective solution is compressor-based systems as there are no coolant supply or delivery systems, moreover the build cost of exhaust and improvement of ventilation system are considerably high. Mounting of compressor based thermal chamber inside the rotating frame of the test table is possible only by separating the compressor and all electronics from the very chamber by flexible hose.

3) Cost Considerations - Cost to Buy, Operate, and Maintain Compressor-based systems have higher purchase and maintenance costs because they have more mechanical components (compressors, condensers, pumps, etc).

Cryogenic systems have a higher operating cost because they require replenishment of expendable coolants and more training for personnel.

The general difference is that cryogenic cooling is less expensive short term and more expensive long term, while compressor-based cooling is more expensive short term but less expensive long-term.

\section{CONCLUSIONS}

With a plenty of factors to consider, deciding between cryogenic and compressor-based cooling systems can be difficult. Having a full understanding 
of the test requirements and the advantages of each cooling method is critical to making the best decision. For consumer grade MEMS testing using the 3-axes simulation table in NETL facility the better long term option would be compressor-based system with enclosure attached via flexible hose.

\section{REFERENCES}

[1] (2014, Feb) IMU Errors and Their Effects. NovAtel Inc., Application Note [Online]. Available: www.novatel.com/assets/Documents/Bulletins/APN0 64.pdf

[2] (2015, Mar) Acceleration Inertial Sensor MS9000 Colibrys Ltd., Switzerland. Datasheet. [Online]. Available: www.colibrys.com/pro-cats/inertial-sensor/

[3] S. K. Hong and S. Park, "Minimal-drift heading measurement using a MEMS gyro for indoor mobile robots," Sensors, no. 8, pp. 7287-7299, 2008.

[4] F. Rudolf, S. Gonseth, R. Brisson, and P. Krebs, "New generation of high performance/high reliability MEMS accelerometers for harsh environment," in IEEE/ION Position, Location and Navigation Symposium - PLANS 2014, Monterey, CA, May 2014 pp. 7-11.

[5] (2014, Nov) 3 Factors that Determine a Cooling Method for Electronics Testing. inTEST Corporation, Mt. Laurel, New Jersey, USA Application Note. [Online]. Available: www.intesthermal.com/ cryogenic-vs-compressor-cooling
[6] V. Szekely, M. Rencz, and B. Courtois, "Thermal testing methods to increase system reliability," in Proc. 13th IEEE SEMITHERM Symposium, 1997, pp. 210-217.

[7] J. Draper, J. Block, J. Koller, and C. Steele, "Thermal management in embedded systems using MEMS," in Proc. Lecture Notes in Computer Science 1388 (IPPS/SPDP'98 Workshops Proceedings), 1998, pp. 900-901.

[8] M. El-Diasty, A. El-Rabbany, and S. Pagiatakis, "Stochastic characteristics of temperature-dependent MEMS-based inertial sensor error," in Proceedings of the 2006 National Technical Meeting of The Institute of Navigation, Monterey, CA, January 2006, pp. 1017-1027.

[9] H. Huiping, Z. Binzhen, and Z. Wendong, "Study of accelerometer's temperature compensation by software and hardware," Proceedings of the International Symposium on Test and Measurement, vol. 1, 4th International Symposium on Test and Measurement (ISTM/2001), Jun 1-3, 2001, Shanghai, pp. 841-843.

[10]K. Shcheglov, C. Evans, R. Gutierrez, and T. K. Tang, "Temperature dependent characteristics of the JPL silicon MEMS gyroscope," IEEE Aerospace Conference Proceedings, vol. 1, Mar 18-25, 2000, Big Sky, MT, pp. 403-411.

Received January 25, 2017

Sineglazov Viktor. Doctor of Engineering Science. Professor.

Educational \& Research Institute of Information and Diagnostic Systems, Aviation Computer-Integrated Complexes Department, National Aviation University, Kyiv, Ukraine.

Education: Kiev Polytechnic Institute. Kiev, Ukraine (1973).

Research interests: Air Navigation, Air Traffic Control, Identification of Complex Systems, Wind/solar power plant, Neural Network.

Publications: more than 600 papers.

E-mail: svm@nau.edu.ua

Dolgorukov Sergey. Post-graduate student.

Aviation Computer-Integrated Complexes Department, Educational \& Research Institute of Information and Diagnostic Systems, National Aviation University, Kyiv, Ukraine.

Education: National Aviation University, Kyiv, Ukraine (2013).

Research area: hardware in-the-loop simulation, unmanned aerial vehicle, navigation complexes.

Publications: 8 .

E-mail: sdolgorukov@nau.edu.ua

В. М. Синєглазов, С. О. Долгоруков. Термокамера для випробувального стенду навігаційного обладнання Термокамери є важливим інструментом для тестування навігаційного обладнання в умовах близьких до реальних. У даній статті описуються конструктивні і експлуатаційні характеристики термокамер щодо застосування в випробуваннях мікроелектромеханічних систем різного принципу дії. Крім того, при оптимізації параметрів термокамери враховуеться, що вона повинна розташовуватися всередині внутрішньої рами карданового підвісу трьохосевого випробувального стенду. Представлено методологію вибору технічних засобів температурної камери для випробувального стенду навігаційного обладнання. Представлено процедуру вирішення завдання вибору температурної камери для випробувань інерційних датчиків на основі мікроелектромеханічних систем. Обгрунтовано параметри і характеристики камери, які зводять до мінімуму витрати на виробництво та експлуатацію системи. 
Ключові слова: кліматичні випробування; мікроелектромеханічні системи; випробувальний стенд; похибка вимірювання.

Синєглазов Віктор Михайлович. Доктор технічних наук. Професор.

Кафедра авіаційних комп'ютерно-інтегрованих комплексів, Навчально-науковий інститут інформаційно-діагностичних систем, Національний авіаційний університет, Київ, Україна.

Освіта: Київський політехнічний інститут. Київ, Україна (1973).

Напрям наукової діяльності: аеронавігація, управління повітряним рухом, ідентифікація складних систем, вітроенергетичні установки.

Кількість публікацій: більше 600 наукових робіт.

E-mail: svm@nau.edu.ua

Долгоруков Сергій Олегович. Аспірант.

Кафедра авіаційних комп'ютерно-інтегрованих комплексів, Національний авіаційний університет, Київ, Україна. Освіта: Національний авіаційний університет, Київ, Україна (2013).

Напрям наукової діяльності: напівнатурні випробування, безпілотні літальні апарати, навігаційні комплекси.

Кількість публікацій: 8.

E-mail: sdolgorukov@nau.edu.ua

В. М. Синеглазов, С. О. Долгоруков. Термокамера для испытательного стенда навигационного оборудования

Термокамеры являются важным инструментом для тестирования навигационного оборудования в условиях близких к реальным. В данной статье описываются конструктивные и эксплуатационные характеристики термокамер в отношении применения в испытаниях микроэлектромеханических систем разного принципа действия. Кроме того, при оптимизации параметров термокамеры учитываюется, что она должна располагаться внутри внутренней рамы карданового подвеса трехосевого испытательного стенда. Представлена методология выбора технических средств температурной камеры для испытательного стенда навигационного оборудования. Представлена процедура решения задачи выбора температурной камеры для испытаний инерциальных датчиков на основе микроэлектромеханических систем. Обоснованы параметры и характеристики камеры, которые сводят к минимуму затраты на производство и эксплуатацию системы.

Ключевые слова: климатические испытания; микроэлектромеханические системы; испытательный стенд; погрешность измерений.

Синеглазов Виктор Михайлович. Доктор технических наук. Профессор.

Кафедра авиационных компьютерно-интегрированных комплексов, Учебно-научный институт информационно-диагностических систем, Национальный авиационный университет, Киев, Украина.

Образование: Киевский политехнический институт. Киев, Украина (1973).

Направление научной деятельности: аэронавигация, управление воздушным движением, идентификация сложных систем, ветроэнергетические установки.

Количество публикаций: более 600 научных работ.

E-mail:svm@nau.edu.ua

Долгоруков Сергей Олегович. Аспирант.

Кафедра авиационных компьютерно-интегрированных комплексов, Учебно-научный институт информационно-диагностических систем, Национальный авиационный университет, Киев, Украина.

Образование: Национальный авиационный университет, Киев, Украина (2013).

Направление научной деятельности: полунатурное моделирование, беспилотные летательные аппараты, навигационные комплексы.

Количество публикаций: 8.

E-mail: sdolgorukov@nau.edu.ua 